\title{
Keragaan perikanan tuna hand line 5-10 GT yang berpangkalan di Pelabuhan Perikanan Samudera Bitung
}

\author{
The performance of tuna hand line 5-10 GT fishery in Bitung Oceanic Fishing Port \\ RuSLY H.A. SORA*, FAnNy SiloOy dan MARIANA E. KAYADOE \\ Program Studi Pemanfaatan Sumberdaya Perikanan, Fakultas Perikanan dan Ilmu Kelautan, \\ Universitas Sam Ratulangi, Manado 95115
}

\begin{abstract}
Tuna hand lines have been used widely by fishermen in Sulawesi Sea and its surrounding to catch big pelagic species with small fishing boats. Although the gear design has evolved over centuries, there is still potential for improving its catching efficiency and selectivity. This study aimed to describe the performance of tuna hand line 510GT in terms of technical, economic and social. The performance of the technical analysis approach is obtained through the comparison of production with production variables, the analysis of the economic performance of production values obtained by comparison with the variable production and analysis of social performance obtained from calculating the income of fishermen and compared with a kilogram of rice. The results of the eight ships samples showed that the average production per trip is $340.96 \mathrm{~kg}$; Average production per worker $783.41 \mathrm{~kg}$. Catch to break even showed the smallest percentage in KM Anan 01 amounted to $43.63 \%$ and the highest at KM Kartika 45 amounted to $104.30 \%$. Average income per trip is Rp.17,321,644, the average profit per trip Rp.5,953,334 average income per year is Rp.25,110,217 and an average profit per year is Rp.96,876,941. The results of the analysis of RC-Ratio for the eight vessels during the two years of operation were 1.69. The average return on investment was $36 \%$. Results of the analysis showed that the social performance of each of the crew who have amenability more than two people, then on average each person requires $332 \mathrm{~kg}$ of rice $<360 \mathrm{~kg}$ of rice, means including poor families.
\end{abstract}

Keywords: analysis of the technical, economic, social

\begin{abstract}
ABSTRAK
Pancing ulur tuna telah digunakan secara luas oleh nelayan di Laut Sulawesi dan sekitarnya untuk menangkap ikan pelagis besar dengan kapal-kapal ukuran kecil. Walaupun konstruksinya telah berkembang sejak lama, tetapi masih memiliki potensi untuk meningkatkan efisiensi penangkapan dan selektivitasnya. Penelitian ini bertujuan untuk mendeskripsikan keragaan perikanan tuna hand line 5-10GT dari segi teknis, ekonomi dan sosial. Pendekatan analisis keragaan teknis diperoleh melalui perbandingan produksi dengan variabel produksi, analisis keragaan ekonomis diperoleh melalui perbandingan nilai produksi dengan variabel produksi dan analisis keragaan sosial didapat dari menghitung pendapatan nelayan dan dibandingkan dengan kilogram beras. Hasil penelitian dari delapan kapal sampel menunjukan bahwa rata-rata produksi per trip sebesar 340,96 kg; rata-rata produksi per tenaga kerja $783,41 \mathrm{~kg}$. Catch to break even menunjukkan persentase terkecil pada KM Anan 01 sebesar 43,63\% dan yang tertinggi pada KM Kartika 45 sebesar 104,30\%. Rata-rata pendapatan per trip sebesar Rp.17,321,644, rata-rata keuntungan per trip sebesar Rp.5,953,334 rata-rata pendapatan per tahun sebesar Rp.25,110,217 dan rata-rata keuntungan per tahun sebesar Rp. 96.876.941. Hasil analisis RC-Ratio kedelapan kapal selama dua tahun operasi adalah 1,69. Rata-rata pengembalian investasi sebesar 36\%. Hasil analisis keragaan sosial menunjukkan bahwa setiap anak buah kapal yang mempunyai tanggungan lebih dari dua orang, maka rata-rata setiap orang membutuhkan $332 \mathrm{~kg}$ beras < $360 \mathrm{~kg}$ beras, berarti termasuk dalam kelompok keluarga miskin.
\end{abstract}

Kata-kata kunci: analisis teknis, ekonomis, sosial

\footnotetext{
*Penulis untuk penyuratan; email: ruslysora@gmail.com
} 


\section{PENDAHULUAN}

Pembangunan sektor perikanan di Indonesia diharapkan dapat memberikan kontribusi terhadap tiga komponen penting tujuan pembangunan nasional, yaitu pertumbuhan ekonomi (progrowth), perluasan lapangan kerja (projob) dan penurunan tingkat kemiskinan (propoor) (Setiawan, 2007 dalam Yafis, dkk., 2009).

Tampubolon (1980) mengemukakan bahwa untuk menjalankan usaha perikanan, pada perusahaan-perusahaan yang besar maupun yang kecil, dibutuhkan kemampuan managerial untuk melaksanakan fungsi-fungsi manajemen dengan baik sehingga semua orang yang bekerja dan fasilitas yang tersedia di perusahaan, benar-benar dapat digerakkan dan diarahkan untuk mencapai tujuan perusahaan seefisien dan seekonomis mungkin.

Komoditas hasil tangkapan utama di Kota Bitung adalah ikan pelagis besar dari jenis ikan tuna dan cakalang. Data menunjukkan, khusus untuk volume produksi ikan tuna ekor kuning dalam lima tahun terakhir yaitu tahun 2007 hingga 2011 mengalami peningkatan sebesar 28\% dari 37.500 ton menjadi 48.000 ton (Dinas Kelautan dan Perikanan Kota Bitung, 2012 dalam Wijaya, dkk., 2012).

Hand line merupakan pancing yang sangat sederhana. Alat ini hanya terdiri dari tali pancing, mata pancing dan umpan. Operasinya sangat sederhana karena bisa dilakukan oleh satu orang. Jumlah mata pancing bisa satu buah, bisa juga lebih, bisa menggunakan umpan asli dan umpan palsu, pemancingan bisa dilakukan di rumpon dan perairan lainnya (von Brandt,1984).

Informasi tentang keragaan teknis, ekonomis dan sosial dari perikanan tuna hand line masih kurangnya. Oleh sebab itu, menghadapi perubahan-perubahan kebijakan pemerintah dalam dunia usaha perikanan maka perlu ada kajian terhadap keragaan usaha perikanan tuna hand line yang didaratkan di Pelabuhan Perikanan Samudera (PPS) Bitung.

Tujuan penelitian ini yaitu untuk menilai keragaan perikanan tuna hand line 5-10 GT menyangkut keragaan teknis, keragaan ekonomis, dan keragaan sosial. Penelitian ini diharapkan dapat memberikan informasi ilmiah bagi ilmu dan menjadi bahan informasi bagi usaha perikanan tuna hand line dengan kapal 5-10 GT.

Penelitian ini dilakukan PPS Bitung selama 3 bulan mulai 1 September 2015 sampai 30 Novem- ber 2015, yang meliputi pengumpulan data dan informasi di pelabuhan, serta mengikuti operasi penangkapan.

\section{METODE PENELITIAN}

Penelitian ini menggunakan metode penelitian deskriptif dengan pendekatan survei. Data yang dikumpulkan adalah aktivitas kapal tuna hand line ukuran 5-10 GT yang mendaratkan hasil tangkapan di PPS Bitung. Sebagai sampel diambil delapan buah kapal yang memiliki data kegiatan penangkapan, produksi, biaya serta pendapatan selama tahun 2014 dan 2015 cukup lengkap tercatat di PPS Bitung, masing-masing KM Glory-09, KM Rahmatullah-01, KM Triple D-01, KM Barakati, KM Berkat bahari-01, KM Kartika-45, KM Adnan-01 dan KM Yasin-05.

Analisis keragaan teknis dinilai dengan menghitung hasil tangkapan minimum yang harus diperoleh untuk mengembalikan total biaya yang dikeluarkan dalam satu tahun atau hasil tangkapan pada keadaan di mana biaya sama dengan pendapatan, diistilahkan dengan catch to break even, dengan formula yang dikemukakan oleh Apituley (1987) sebagai berikut:

$$
\text { Catch to break even }=\frac{\text { Total Biaya Tahunan }}{\text { Harga ikan per kg }}
$$

Analisis keragaan ekonomis dinilai dengan membandingkan parameter-parameter sebagaimana dikemukakan oleh Apituley (1987) sebagai berikut:

- Pendapatan kotor per biaya total (RC-Ratio)

- Laju pengembalian investasi (Vi):

$$
\mathrm{Vi}=\frac{\text { Keuntungan }+ \text { Biaya Penyusutan }}{\text { Investasi }}
$$

Pengukuran tingkat kemiskinan pada keluarga nelayan digunakan kriteria yang dikemukakan oleh Sayogyo (1977) dalam Novahadi, dkk., (2008) sebagai berikut:

- Kelompok miskin sekali: pendapatan setara dengan nilai tukar beras $240-360 \mathrm{~kg} / \mathrm{kapita} /$ tahun

- Kelompok miskin: pendapatan setara dengan nilai tukar beras 360-460 kg/kapita/tahun

- Kelompok cukup: pendapatan setara dengan nilai tukar beras 480-960 kg/kapita/tahun 
- Kelompok kaya: pendapatan setara dengan nilai tukar beras $>960 \mathrm{~kg} / \mathrm{kapita} / \mathrm{tahun}$.

\section{PEMBAHASAN}

\section{Analisis catch to break even.}

Hasil analisis catch to break even dari kedelapan kapal sampel disajikan pada Tabel 1. Dari hasil analisis catch to break even dapat dilihat bahwa produksi yang dihasilkan kapal KM Triple D-01 tidak mencukupi untuk dapat mengembalikan seluruh biaya operasi yang dikeluarkannya dalam satu tahun. KM Kartika-45 memperoleh produksi yang menghasilkan keuntungan lebih dari 100\%, KM Adnan-01 memperoleh produksi yang menghasilkan keuntungan di bawah 50\%, dan 5 (lima) kapal lainnya memperoleh produksi yang menghasilkan keuntungan di atas 50\%.

\section{Analisis Revenue Cost Ratio (RC-Ratio)}

Hasil analisis Revenue Cost Ratio (RC-Ratio) dari kedelapan kapal sampel disajikan pada Tabel 2.
Hasil analisis RC-Ratio menunjuk kepada besarnya persentase pendapatan kotor terhadap biaya total yang dikeluarkan. Kriteria keputusan dalam analisis ini yaitu jika nilai $R C$-Ratio lebih besar dari satu, maka usaha mengalami keuntungan karena pendapatan kotor lebih besar dari biaya total. Jika nilai $R C$-Ratio kurang dari satu maka usaha mengalami kerugian karena pendapatan kotor kurang dari biaya total yang dikeluarkan. Jika nilai $R C$-Ratio sama dengan satu maka usaha pulang pokok atau tidak mengalami keuntungan maupun kerugian.

Hasil analisis $R C$-Ratio memperlihatkan bahwa nilai $R C$-Ratio rata-rata setiap kapal setiap tahun sebesar 1,69. Jadi semua biaya yang dikeluarkan dapat dikembalikan dengan kelebihan (keuntungan) sebesar $69 \%$ per tahun. KM Tripel D-01 memperoleh nilai $R C$-Ratio lebih kecil dari satu atau sebesar 0,71 yang berarti bahwa kapal ini mengalami kerugian rata-rata sebesar 29\% setiap tahun dari total biaya yang dikeluarkan.

Tabel 1.Catch to Break Even

\begin{tabular}{llccccc}
\hline No & \multicolumn{1}{c}{ Nama Kapal } & $\begin{array}{c}\text { Biaya Rata - } \\
\text { Rata }(\mathbf{R p})\end{array}$ & $\begin{array}{c}\text { Harga } \\
\text { Ikan }(\mathbf{R p})\end{array}$ & Ctbe & $\begin{array}{c}\text { Produksi } \\
(\mathbf{K g})\end{array}$ & $\begin{array}{c}\text { Prod/Ctbe-1 } \\
\times \mathbf{1 0 0}\end{array}$ \\
\hline 1 & KM Glory-09 & 135.790 .000 & & $2.715,80$ & $5.119,50$ & 88,51 \\
2 & KM Rahmatullah-01 & 103.533 .333 & & $2.070,67$ & $3.636,00$ & 75,60 \\
3 & KM Tripel D-01 & 66.570 .000 & & $1.331,40$ & 940,00 & 29,40 \\
4 & KM Barakati & 158.830 .000 & 50.000 & $3.176,60$ & $5.473,00$ & 72,29 \\
5 & KM Berkat Bahari-01 & 135.103 .333 & & $2.702,07$ & $5.365,50$ & 98,57 \\
6 & KM Kartika-45 & 134.270 .000 & & $2.685,40$ & $5.486,00$ & 104,30 \\
7 & KM Adnan-01 & 135.103 .333 & & $2.702,07$ & $3.881,00$ & 43.63 \\
8 & KM Yasin-05 & 147.310 .000 & & $2.946,20$ & $5.054,50$ & 71,62 \\
\hline
\end{tabular}

Tabel 2.Nilai RC-Ratio

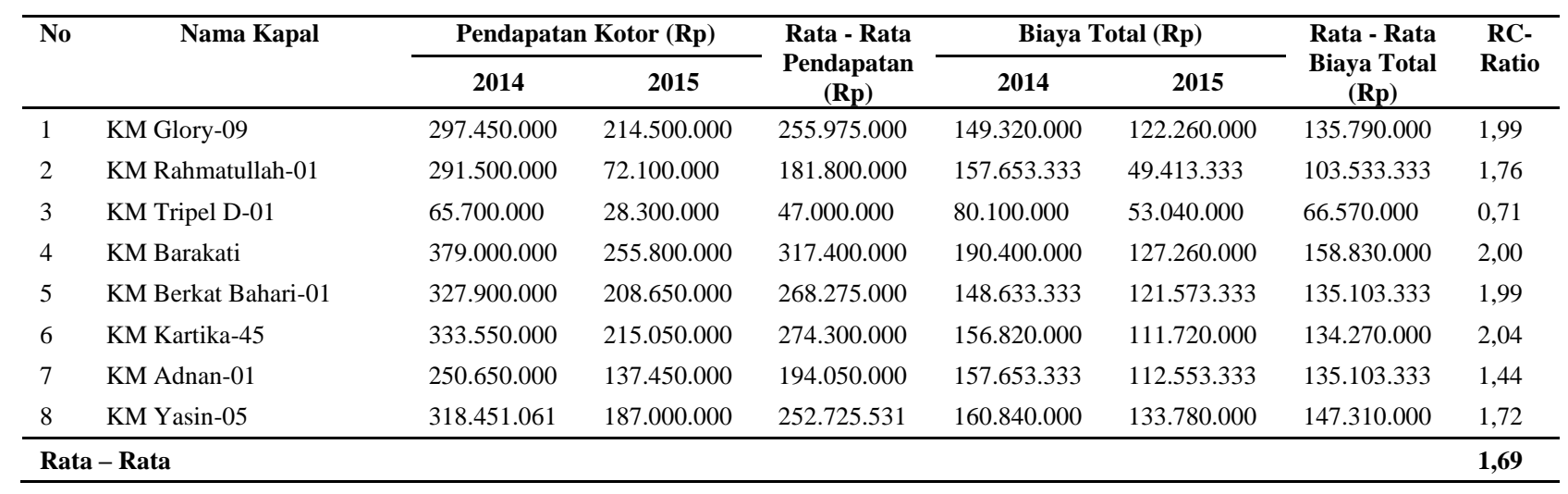


Tercatat ada tiga kapal dari delapan kapal mempunyai nilai $R C$-Ratio mendekati $100 \%$ yaitu: KM Kartika-45 dengan nilai $R C$-Ratio sebesar 2,04 yang berarti kapal ini memperoleh keuntungan sebesar $104 \%$ dari total biaya yang dikeluarkan setiap tahun. KM Barakati mencapai nilai RC-Ratio 2,00 yang berarti kapal ini mengalami keuntungan setiap tahun sebesar $100 \%$ dari total biaya yang dikeluarkan. KM Berkat Bahari-01 mencapai nilai RC-Ratio sebesar 1,99 yang berarti bahwa kapal ini memperoleh keuntungan sebesar 99\% dari total biaya yang dikeluarkan setiap tahun.

Kapal lainnya yaitu KM Glory-09 menghasilkan keuntungan sebesar $88 \%$ dari total biaya yang dikeluarkan (RC-Ratio 1,89), KM Rahmatulllah01 memperoleh keuntungan sebesar $76 \%$ dari biaya total yang dikeluarkan (nilai RC-Ratio 1,76\%). KM Yasin-05 memperoleh keuntungan sebesar $72 \%$ dari total biaya yang dikeluarkan (nilai $R C$-Ratio 1,72). KM Adnan-01 mengalami keuntungan sebesar $44 \%$ dari total biaya yang dikeluarkan (nilai $R C$-Ratio 1,44).

\section{Pengembalian investasi}

Hasil analisis pengembalian investasi dari kedelapan kapal sampel disajikan pada Tabel 3. Pengembalian investasi menunjukkan besarnya persentase modal yang dapat dikembalikan setiap tahun. Hasil analisis memberikan petunjuk bahwa usaha perikanan tuna hand line dengan kapal 5-10 GT mempunyai laju pengembalian investasi yaitu ratarata $36 \%$ dengan laju pengembalian investasi paling lama dicapai 2-3 tahun usaha. Hasil analisis setiap kapal menunjukkan bahwa ada 4 (empat) buah kapal yang usaha modal sudah dapat dikembalikan yaitu KM Glory-09, KM Barakati, KM Berkat Bahari-01 dan KM Yasin-05.

Tabel 3. Pengembalian investasi

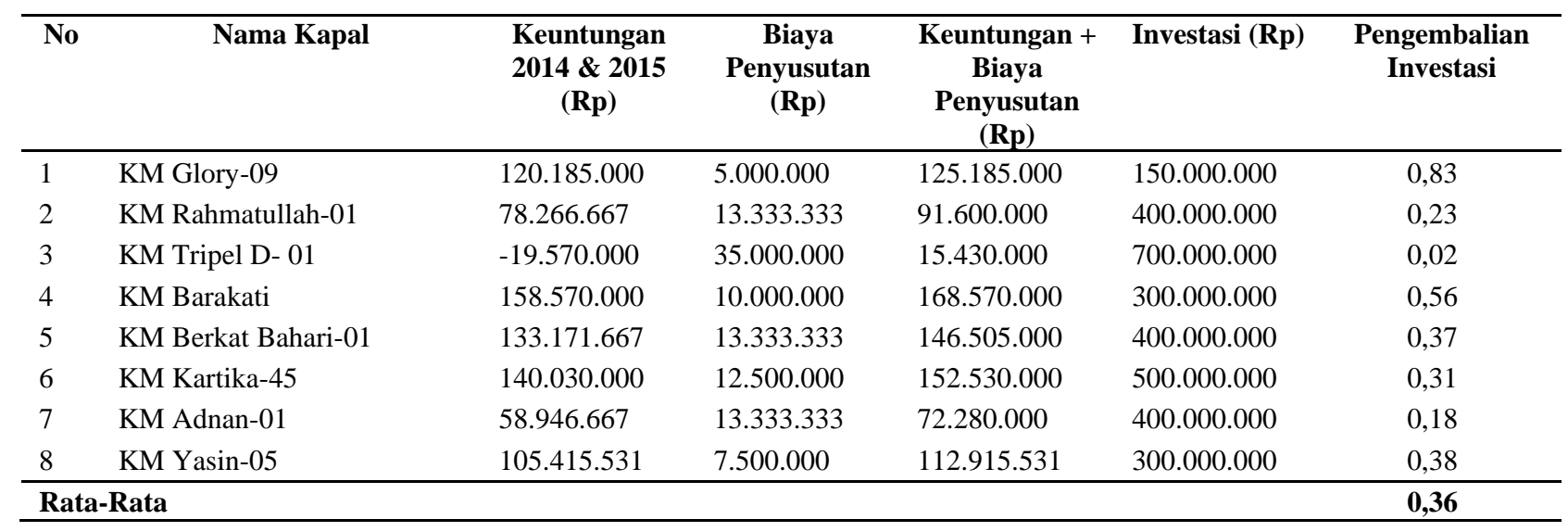

Tabel 4: Analisis keragaan sosial

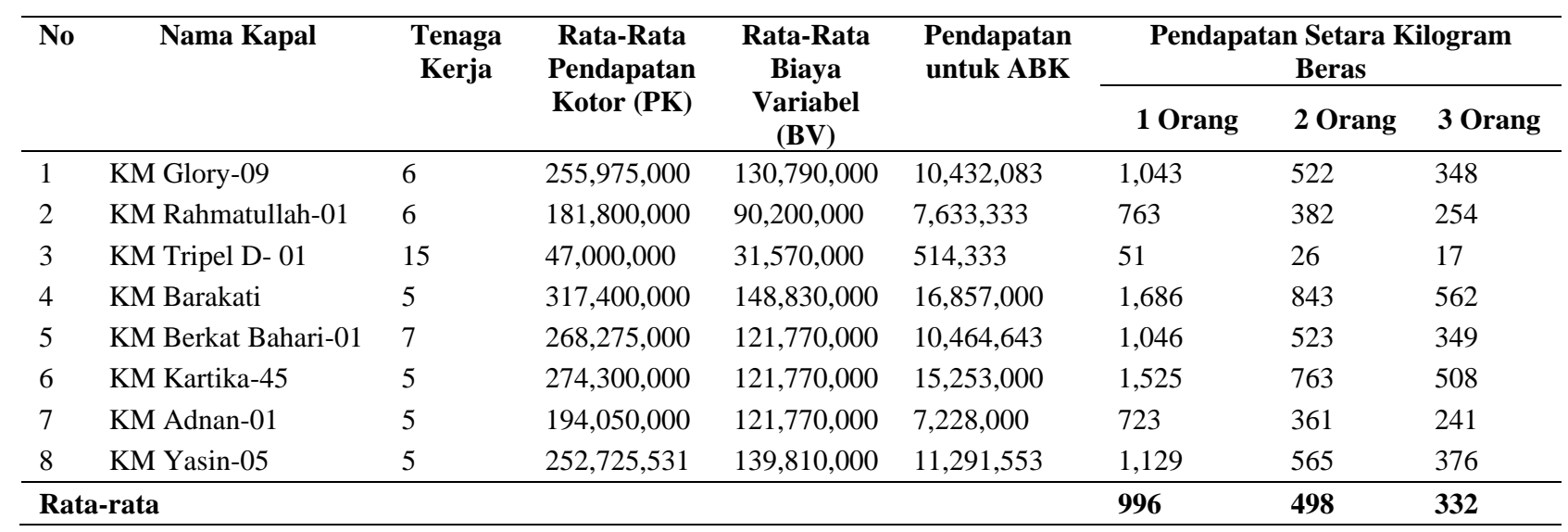




\section{Analisis keragaan sosial}

Hasil analisis pengembalian investasi dari kedelapan kapal sampel disajikan pada Tabel 4. Analisis keragaan sosial dilakukan dengan membandingkan tingkat pendapatan nelayan secara individu dengan kriteria tingkat kemiskinan yaitu pendapatan setara dengan harga kilogram beras. Hasil analisis pendapatan per ABK setara beras pada Tabel 4 menunjukkan bahwa nelayan yang sudah berkeluarga dan mempunyai seorang anak atau mempunyai tanggungan sebanyak tiga orang maka hanya $\mathrm{ABK}$ pada dua buah kapal yang tergolong dalam kategori hidup cukup yaitu KM Barakati dan KM Kartika-45 sedangkan kapal lainnya tergolong nelayan miskin.

\section{KESIMPULAN}

1) Tujuh kapal tuna hand line 5-10 GT yang berpangkalan di PPS Bitung secara teknis dapat mencapai target produksi minimum sedangkan satu kapal tidak.

2) Secara ekonomis, RC-Ratio rata-rata per kapal per tahun sebesar $69 \%$; laju pengembalian investasi yaitu rata-rata $36 \%$ selama $2-3$ tahun.

3) Secara sosial, anak buah dari dua kapal tergolong hidup cukup, sedangkan anak buah dari enam kapal tergolong miskin.

\section{DAFTAR PUSTAKA}

Apituley, 1987. Analisa teknis dan ekonomis usaha penangkapan skipjack dan tuna purse-seine. Skripsi. Fakutas Perikanan dan Ilmu Kelautan, Universitas Pattimura, Ambon.

Baskoro, M.S. dan A. Effendi. 2005. Tingkah laku ikan hubungannya dengan metode pengoperasian alat tangkap ikan. Departemen Pemanfaatan Sumberdaya Perikanan Fakultas Perikanan dan Ilmu Kelautan Institut Pertanian Bogor, Bogor.

Labaro, I.L., E.M. Katiandagho, E. Reppie, dan J. Budiman. 2008. Pengaruh larutan minyak cumi terhadap hasil tangkapan pancing ulur tuna di perairan sekitar Pulau Batang Dua. Prosiding Konferensi Nasional VI, Pengelolaan Sumberdaya Pesisir dan Lautan.

Novahadi, R., A. Muani, dan Imelda. 2013. Analisis tingkat kesejahteraan keluarga petani kebun plasma kelapa sawit. PT. Prakarsa Tani Sejati.

Tampubolon, A.H. 1980. Manajemen usaha perikanan purse seine. Karya Ilmiah. Fakultas Perikanan dan Ilmu Kelautan Institut Pertanian Bogor, Bogor.

von Brandt, A. 1984. Fishing Catching Methods of the World. Third Edition. Fishing New Book, Farham.

Wijaya, A.R., H.M. Huda, dan Manadianto. 2012. Penguasaan aset dan struktur pembiayaan usaha penangkapan ikan tuna menurut musim yang berbeda. Balai Besar Penelitian Sosial Ekonomi Kelautan dan Perikanan.

Yafis, M., M.F.A. Sondita, S. Soemakaryo, D.R. Monintja. 2009. Analisis finansial usaha penangkapan ikan dalam model perbaikan kesejahteraan nelayan di Kabupaten Rokan Hilir Provinsi Riau. Jurnal Perikanan dan Kelautan14(1):81-92. 